\title{
Tüketicilerin Banka Tercihlerinde Marka Denkliği Ve Marka İmajı Arasındaki İlişkinin Değerlendirilmesi
}

DOI: 10.26466/opus.563431

*

\author{
Burcu Oralhan* - Nuh Mehmet Özlü** \\ * Dr, Öğr. Üyesi, Nuh Naci Yazgan Üniversitesi, İiBF, Kocasinan/Kayseri/Türkiye \\ E-Posta: boralhan@nny.edu.tr \\ ORCID: $\quad$ 0000-0001-8905-0140 \\ ** Yüksek Lisans Öğrencisi, Nuh Naci Yazgan Üniversitesi, İ̈BF, Kayseri/Türkiye \\ E-Posta: nuh.mehmet@windowslive.com \\ ORCID: $\quad$ 0000-0003-2800-6095
}

\section{Öz}

Güçlü bir marka, bugün uluslararası entegrasyon ve zorlu rekabet şartları altında sürdürülebilir büyümeyi amaçlayan herhangi bir işletmenin en önemli varliklarından biridir. Teknolojik gelişmelerle birlikte bankactlık sektöründe ürün ve hizmetlere yönelik uygulanan değişimler rekabet ortamına ivme kazandırmıştır. Işletmeler tarafindan sunulan ürün ve hizmetlere yönelik markaların değerlendirilmesinde marka imajı, marka denklĭği ve marka denklĭginin alg̨lanan kalite, marka çă̆rışılmları, marka bilinirliliği ve marka bă̆lllığından oluşan boyutlarının önemi zamanla anlaşılmaya başlamıştır. Bu araştırmanın amacı, bankacılık hizmetlerinden faydalanan tüketicilerin demografik özelliklerinin tercih ettikleri bankaların marka denkliği, denkliğin alt boyutları ve marka imajı arasındaki ilişkilerin belirlenmesi ve demografik değişken grupları arasında var ise farklilıkların ortaya çıkarılmasıdır. Bu amaç doğrultusunda, Kayseri ilinde ikamet eden tüketicilere yönelik 387 anket uygulanmış ve ölçek güvenilirlikleri hesaplanmıştır. Araştırma kapsamında veri analizi SPSS 22 paket programında, tanımlayıci istatistikler, Spearman korelasyon ve Kruskal Wallis analizinden faydalanılarak yapılmıştır. Yapılan analizlerinin sonucuna göre marka bağ̆llığı ile ö̆grenim durumu, yaş ve banka kullanım süresi arasında, kullanım süresi ile marka çağrışımı, algılanan kalite ve marka denkliği arasında ilişkiler tespit edilmiştir. Marka imajı ile marka çă̆rışımları, marka bilinirliği, algılanan kalite ve marka denkliği arasında da ilişkiler olduğu görülmüş̧ür. Yaş grupları açısından incelendiğinde 50 yaş ve üstü olan katılimcılarıda marka bilinirliğinin daha yüksek, lisansüstü öğrenim gören bireylerin lise ve dengi öğrenim gören bireylere göre marka çağrışımlarının daha yüksek, bankalarda kullanım süresi 15 yıl ve üzeri olan katılımcılarda, 1yıl ve daha az olanlara göre marka çă̆ırışımı, algılanan kalite ve marka denkliklerinin daha yüksek olduğu anlaşılmıştır. Sonuç olarak işletmelerin, müşteri potansiyelini artırabilmeleri müşterilerileri demografik özelliklerine göre değerlendirerek, marka denkliği boyutlarıyla birlikte göz önüne alarak imajlarını artırmaları gerekmektedir. Marka denkliği boyutlarını ve marka imajın iyileştirecek ve geliştirecek çözümler oluşturmak, bankalar için önemli bir marka stratejisi olarak belirlenmelidir.

Anahtar Kelimeler: Marka denkliği, Marka imajl, Demografik değiş̧kenler, Bankalar, Marka denkliği boyutları 


\title{
Evaluating The Relationship Between Brand Equity and Image of Customers Bank Preferences
}

\begin{abstract}
Today, a strong brand is one of the most important assets of any business aiming at sustainable growth under international integration and challenging competition. Along with technological developments, changes in the banking sector related to products and services have accelerated the competitive environment. The importance of brand image, brand equity and brand equity in terms of perceived quality, brand connotations, brand awareness and brand loyalty has started to be understood in the evaluation of brands for products and services offered by enterprises. The aim of this study is to determine the relationships between the demographic characteristics of the consumers who benefit from banking services and the brand equity of the banks they prefer, the sub-dimensions of the equity and the brand image and also to determine the differences between the demographic variables. For this purpose, 387 questionnaires were applied to consumers residing in Kayseri and scale reliability was calculated. In the scope of the research, data analysis was done by using SPSS 22 package program with the help of descriptive statistics, Spearman correlation and Kruskal Wallis analysis. According to the results of the analyzes, the relationships between brand loyalty and educational status, age and bank usage period and the relationships between the usage period and perceived quality, brand equivalence and brand connotations were determined. There were also relations between brand image and brand associations, brand awareness, perceived quality and brand equity. When the age groups are examined, it is seen that the brand awareness is higher in the participants aged 50 and over and individuals with postgraduate education have higher brand associations than high school and equivalent students. Furthermore, it is understood that the number of brand call, perceived quality and brand balances were higher than those with 1 year or less in the banks with a usage period of 15 years or more. As a result, enterprises need to increase their customer potential by evaluating the customers according to their demographic characteristics and increasing their image by considering the dimensions of brand equity together. Establishing solutions to improve and develop brand equity dimensions and brand image should be identified as an important brand strategy for banks.
\end{abstract}

Keywords: Brand equity, Brand image, Demographic variables, Banks, Brand equity dimensions 


\section{Giriş}

Küreselleşmenin yavaş yavaş etki göstermeye başlaması ve ekonomik sektördeki gelişmeler neticesinde eski çağların sınırlı imkânlarına sahip, küçük sermayeli ve dağınık bankalarının yerine, hemen bütün ülkelerde, geniş sermaye ve büyük finansal imkânlara sahip, çok şubeli "dev bankaları" ortaya çıkarmıştır. Günümüz şartlarında sahip olunan Türk bankacılık mali verileri her geçen gün artarak ilerlemektedir. Sahip olduğu mali yapısının sağlam olması, gelişmiş teknoloji kullanımı, sunmuş olduğu hizmetlerin kaliteli oluşu, yeni ürün ve hizmet ağları, denetleyici kurumları, yasaları yanı sıra, Türk bankacılık sektörü verileri uluslararası düzeyde yerini almıştı (Sümer, 2016, s.487).

Banka; mali sistem içerisinde gerçek, tüzel ve kamusal kişilerin kredi işlemlerini gerçekleştirip ödemeler ve alacaklarda kolaylık sağlayan, çeşitli hizmetlerle paranın ticaretini yaparak tasarrufların yatırıma dönüşmesi için fon oluşturan finansal bir kuruluştur (Eyüpgiller, 1988, s.22). Bankalar değişen ve gelişen teknoloji ile beraber müşteri istek ve ihtiyaçlarına göre hizmet sunan kuruluşlar haline gelmesi zorunlu hale gelmiştir. Piyasada artan rekabet ortamı ve mevcut bankaların ucuz hizmetler sunuyor olması müşterilerin fikirlerini ve tercihlerini etkilemektedir. Bankacılık sektöründe en önemli faktörü de bu yüzden dolayı müşteri kavramı oluşturmaktadır (Tepegöz, 2012, s.15). Sunulan hizmetlerle yeni müşteriler elde etmek kadar mevcut bulunan müşterilerinde sadakatini sağlamak olmalıdır. Bu yüzden bankaların müşteri ile en çok vakit geçiren müşteri hizmetleri birimine ve müşteri ilişkileri kavramına büyük önem vermeleri gerekmektedir.

Bankalar açısından artık sunulan kart işlemleri, fonlar, para yatırma ve çekme işlemleri ve hatta izlenen fiyatlama politikaları bile benzerlik göstermeye başlamış, taklit edilebilmesi çok kolay duruma gelmiştir (Tepegöz, 2012, s.15). Bankanın müşterileri ile olan ilişkisi uzun dönemli hale getirebilmesi için sunduğu hizmetlerin yanısıra tüketicilerin sadakatini, kalite algısını, tüketici gözündeki imajı gibi değerlerini de yükseltmesi gerekmektedir. Bu sayede şiddetli rekabet ortamında sadık müşterilerin oluşmasına ve yeni müşterilerin de kazanılmasına olanak sağlayacaklardır.. 
Tüketicilerin markaya yönelik sergilediği tutumlar ve markalarla olan ilişkilerinin açıklanabilmesi için marka denkliği (MD) kavramı ortaya çıkmıştır (Yapraklı ve Can, 2009, s.267). Marka denkliği, bir markanın zaman içinde kazandığ 1 şerefiyeden ve adın tanınmasından elde edilen ve rakip markalara karşı daha yüksek satış hacmine ve daha yüksek kar marjlarına dönüşen güç anlamına gelmektedir (Subramaniam vd., 2014). Müşteri Temelli Marka Denkliği (MTMD), tüketicinin marka denkliği perspektifini temsil etmektedir (Keller, 2001), Ukpebor ve Ipogah (2008) marka değerinin algılanan kalite, marka sadakati ve marka imajı olmak üzere üç boyuttan oluştuğunu ifade etmektedir. Aaker (1991) ve Keller (1993) tarafından geliştirilen marka denkliği modelleri en yaygın kullanılan modellerdir. Yoo ve Donthu'ya (2001) göre, MTMD ölçeği, bilgilerin işlenmesi ve satın alma kararına güven duyulması ve pazarlama programlarını, fiyat, karların, marka genişletmelerinin ve ticari kaldıraçların verimliliğini ve etkinliğini artırmak için işlevsel bir araç olarak tanımlanmıştır. Aaker (1991) modelinde; marka denkliğini oluşturan değiş̧kenleri marka farkındalığı, marka çağrışımları, algılanan kalite, marka çağrışımları ve diğer marka varlıkları olarak ele almıştır. Keller (1993) ise modelinde marka değerini yüksel seyiyedeki marka farkındalığı ve pozitif bir marka imajına bağlamaktadır. Araştırma modeli Aaker ve Keller tarafından oluşturulan modeler baz alınarak kurgulanmıştır.

$\mathrm{Bu}$ araştırmanın temel amacı, tüketicilerin demografik özelliklerinin tercih ettikleri bankaların marka denkliği, denkliğin alt bileşenleri ve marka imajı üzerindeki etkilerinin ölçülmesi ve demografik değişken grupları arasında var ise farklılıkların ortaya çıkarılmasıdır. Hazırlanan çalışma, kavramsal bir çerçeve sunulması ve sürecin geliştirilmesi için ilgili literatürlerin gözden geçirilmesi ile başlamaktadır. Sonrasında hipotezler geliştirilerek, anket uygulaması yapılmış ve sonuçlar analiz edilmiştir. Araştırmanın son bölümünde ise bazı önerilerde bulunulmuş, sonuçlar incelenmiş ve tartışılmıştır.

\section{Marka Denkliği (MD)}

Marka denkliği, işletmenin müşterilere yönelik sunmuş oldukları markaları yüksek kaliteli olarak algılamasına ve markaya karşı olumlu 
duygular besleyerek bağlılıklarının artmasına katkı sağlamaktadır (İslamoğlu ve Fırat, 2011). Lassar vd. (1995) ise, tüketici temelli marka denkliğini, markanın diğer markalarla karşılaştırıldığında ortaya çıkan tüm üstünlüklerin tüketici tarafından algılanması olarak açıklamaktadır. Aaker'a göre marka denkliği, firmanın tüketicilere sunmuş olduğu ürün ve hizmetler ile sağladığı değeri artıran veya azaltan markanın ismi ve sembolüne bağlı olan varlıklar ile ifade eder. Keller ise, marka denkliğini; müşterilerin markaya karşı zihinlerinde oluşan bilginin pazarlanan markaya göre farklı tepkiler geliştirmesi ile oluşan değer ile ifade eder Aaker'a göre marka denkliği; marka farkındalığı, marka çağrışımları, algılanan kalite ve marka bağlılığı gibi boyutlardan oluşmaktadır (Aaker, 1991, s.16). Pazarlama stratejisi içerisinde tüketici temelli marka denkliğinde işletmelerin diğer işletmelere göre farklı konumda bulunması, marka kalitesinin yüksek olarak algılanıp marka sadakati ile diğer markalara göre güçlü bir rekabet avantajı sağlamaktadır (Koçoğlu ve Aksoy, 2017). Güçlü oluşturulmuş bir marka denkliği güven duygusu oluşturarak algılanan kalite ve marka çağrışımları ile müşterinin memnuniyetinin artmasına yardımc olmaktadır (Sağlam, 2014, s.36). Bunun yanında marka denkliğinin işletmenin pazarlama verimliliğini artırması, ürün ve hizmet farkındalığının sürekliliğini sağlaması, kalite göstergesi olarak yorumlanabilmesi, firmanın ürünlerine/hizmetlerine karşı marka bağlılığı oluşturabilmesi, maliyetleri azaltabilmesi gibi birçok avantajı mevcuttur (Karacan, 2006).

Marka denkliğinin Algilanan Kalite (AKO), Marka Bilinirliliği (Farkındalığı) (MBO), Marka Bağlılığı (Sadakati) (MBaO), Marka Çağrışımlari (MCO) olmak üzere dört temel boyutu bulunmaktadır (Aaker, 1996, s.207).

\section{Algılanan Kalite (AK)}

Algılanan kalite kavramı firmanın sahip olduğu marka denkliği üzerinde önemli etkilere sahip olmaktadır. Bu etkiler sahip olunan markanın rakip markalara göre farklılaşmasına, bağımsızlaşmasına ve müşterilerin satın alma niyetlerinin kolaylaşmasına yardımcı olmaktadır. Müşteriler algılanan kalitesini yüksek buldukları ürün ve hizmetler için fazla para ödemeye istekli durumdadırlar bu da algilanan kalitenin fiyat 
üzerinde yaratmış olduğu etkinin göstergesidir (Karacan, 2006, s.51). Zeithaml algılanan kalitenin marka denkliği unsurları içerisinde önemli bir yere sahip olduğunu düşünmekte ve algılanan kalite ne kadar yüksek olursa marka denkliğinin de o kadar yükseleceğini söylemektedir. Bunula beraber bir işletmenin sahip olduğu ürünün veya markanın müşteriler tarafından belirlenmiş olan algılanan kalitesinin yüksek olması diğer ürün ve markalarının da algılanan kalitesinin yüksek olmasını kolaylaştıracağını ifade etmiştir (Zeithaml (1988, s.3). Algılanan kalite ilk olarak tüketicide sunulan ürün ve hizmetin gerçek kalitesine bakılmaksızın algılanan kalite ile değerlendirmede bulunup, satın alma aşamasında tüketicinin karar vermesine yardımcı olmaktadır.

\section{Marka Bilinirliliği (Farkındalığı) (MB)}

Marka bilinirliliği tüketicilerin o markanın varlığından haberdar olmaları ile birlikte zihinlerinde o markanın oluşmasıdır. Marka bilinilirliği ile açıklamalar yapılırken belirli ürün kategorisinden bahsedildiğinde tüketicinin aklına ilgili olan markanın gelmesidir. Bilinirlik (farkındalık), tüketicinin markayı tanımlayabilme ya da hatırlayabilme yeteneği olarakta tanımlanmaktadır (Pappu vd., 2005). Marka bilinirliliğinin tüketiciler üzerinde yaratmış olduğu en büyük etki ise marka hakkında herhangi bir bilgiye veya çağrışıma sahip olmasalar bile satın alma kararlarında etkin rol oynamasıdır. Bunu gerçekleştirmenin yolu ise ilk önce tüketicilerin o ürünün veya markanın varlığının biliyor olmalarına bağlıdır (Sağlam, 2014, s.47). Marka bilinilirliği kişinin sadece o markanın ismini bilmesi ya da tüketicilerin zihninde oluşturmuş olduğu tanınmışlık olarak değil; mevcut markanın sahip olduğu çağrışımların, algılanan kalitenin ve marka sadakatinin bir bütünü olarak düşünülmesi gerekmektedir. Bu yüzden Marka bilinilirliği marka denkliğinin unsurlarının üzerinde önemli bir etkiye sahip durumdadır (Hoeffler ve Keller, 2003, s.422).

\section{Marka Bağlılığı (Sadakati)(MBa)}

Marka bağlılığı, güçlü duyarlılık şartları altında gerçekleştirilen tekrarlı satın alma davranışı olarak ifade edilmektedir (Kim, Kim ve An, 2003, 
s.345). Marka bağlılığı kavramı kalıcı müşterilerin oluşturulabilmesi için büyük öneme sahiptir. Marka bağl1lı̆̆1 olan tüketiciler diğer rakip firmaların sunmuş oldukları ürün, hizmet ve markalarının aynı tatmini sağlamadığını düşünerek bu markada devamlı olacağını gösteren grubu oluşturmaktadır. (Kim, Kim ve An, 2003, s.345). Sunulan ürün ve hizmetlerin güçlü bir markaya veya yüksek kaliteye sahip olması tüketicilerde tatmin duygusuyla beraber marka bağllı̆ğ da sağlayacaktır. Tüketicilerin yaptıkları işlemlerin bilincinde olmaları ile aynı markayı veya aynı ürünü kullanmaları sonucu oluşan memnuniyet ile olumlu hisler duymalarıyla beraber güçlü duygu, düşünce ve tutumla tekrar tekrar satın alma işlemini gerçekleştireceklerdir. Tüketici için satın alınan markadan sağlanmış memnuniyet kişinin o markaya karşı tutarlı bir şekilde bağlılı̆̆ını artırmakla birlikte başka marka arayışları içine girmesinin de önüne geçmektedir (Karacan, 2006, s.39). Marka bağlllı̆̆1 işletmelere ticari güç sağlamakla beraber pazarlama maliyetlerini de azalmaya yardımcı olur. Uzun dönemli hizmet vermeyi amaçlayan işletmeler ilk amaçları olarak yeni müşteri yaratmak yerine mevcut müşterileri korumaya yönelmelidirler; çünkü yeni müşteri bulmak mevcut müşterileri korumaktan hem daha fazla maliyetli hem de zaman açısından sıkıntı yaratacak bir durum oluşturacaktır. Zaman ve maliyet unsuru açısından işletmenin rahat bir konuma ulaşmasıyla yeni müşterilere yönelmek daha doğru olacaktır (Alemdar ve Dirik, 2016, s. 215-216).

\section{Marka Çağrışımları (MC)}

Marka çağrışımları markanın anlamını içeren ve tüketicinin zihninde yer alan o marka hakkındaki bilgiye bağlı markayla ilgili bilgi bölümü şeklinde tanımlanmaktadır (Keller, 1993, s.3). Bu kavram marka denkliğinin oluşturulmasında markanın diğer markalardan ayırt edilebilmesini kolaylaştıran tüketicilere markayı hatırlatıp zihinlerinde oluşmasını sağlayan her şeydir (Koçoğlu \& Aksoy, 2017, s.76) Marka çağrışımlarındaki diğer önemli unsurlar ise markanın ismi, sembolü, kimliği, iç ve diş sahip olduğu tüm değerleridir (Aaker, 1991). İşletmeler yüksek marka değerlerine ulaşmak istiyorlarsa sahip oldukları marka çağrışımlarını da yükselterek tüketicilerin markayı zihninde tutmasını sağlayan, eşsiz çağrışımlarla hizmet sunmaları gerekmektedir. İşletmel- 
erin marka çağrışımları ile yapmak istedikleri; tüketicilerin bilinçaltlarına daha iyi bir şekilde konumlanarak, olumlu imajlar oluşturmak suretiyle satın alma davranışlarında ve tutumlarında kararlı olmalarını sağlamaktır.

\section{Marka İmajı (MI)}

İmaj, bir kurumun aynı faaliyette bulunan diğer kurumlardan ayrılmasını sağlayan ve farklılıklarını ortaya çıkaran unsurlar olarak tanımlanmaktadır (Çetin ve Tekiner, 2015, s.419). Farklı bir kaynak ise imajı kişilerin, nesnelerin veya kurumların başkaları tarafından algılanmaları ile zihinlerinde oluşturduğu, gerçekleşmesini en çok istediği değerlerin akla gelen özet, resim veya kurumun sembolik görüntüsü olarak ifade etmektedir (Kuşakçıŏlu, 2003, s.172). Bu kavram tüketicilerin bankalara yönelik zihinlerinde oluşan karışıklığı gidererek tercihlerinin şekillenmesini ve kolaylaşmasını sağlayan bir faktör olarak karşımıza çıkmaktadır. Günümüzde sürekli artan rekabet piyasalarında sunulan ürün ve hizmetlerin kolay taklit edilebiliyor olması, bankalarında tüketicileri nezdinde bıraktıkları imajının önemini artırmıştır. Birçok işletme imaj kavramının önemine varmış olup, güçlü bir marka imajı ve değeri oluşturmak için yatırımlar yapmaktadır. Marka imajı, kişilerin belirlenen bir markayı duyduklarında veya gördüklerinde zihninde daha önceden kendileri veya başkaları tarafından oluşmuş marka hakkındaki izlenimlerinin toplamını oluşturmaktadır (Onal, 2000, s.47 akt. Silsüpür, 2014, s.25). Keller, marka imajını marka çağrışımları tarafından tüketicinin zihnine yansitılanlar olarak tanımlarken, Aaker da marka imajının tüketici için önemli olan çağrışımlardan oluşturulabileceğini belirtmiştir (Severi ve Ling, 2013). İşletmelerin ürettikleri ürün ve hizmetlerin taklitlerinin kolay yapılıyor olması ve zaman içerisinde birbirlerinden fazla farklarının bulunmaması işletmeleri markalarına yönelterek "markalaşma" kavramının önemini ortaya çıkarmıştır. Keller (1993) marka denkliğini marka farkındalığı ve pozitif bir marka imajıyla açıklamaktadır. İşletmeler de mevcut ürünlerinin değerlerini artıran, rakiplerinden farklılaşmasını ve kolay ayırt edilebilmesi sağlayan ürün ve hizmet vermeye marka imajını oluşturarak süreçlerini geliştirmeye yönelmişlerdir (Vuran ve Afşar, 2016, s.31). 


\section{Metodoloji}

Araştırmanın amacı, tüketicilerin demografik özelliklerinin tercih ettikleri bankaların marka denkliği, denkliğin alt bileşenleri ve marka imajı arasındaki ilişkilerin belirlenmesi ve demografik değişken grupları arasında var ise farklılıkların ortaya çıkarılmasıdır.

\section{Örneklem ve Veri Toplama Tekniği}

Araştırmanın evrenini Kayseri ilinde bankalardan hizmet alan tüketiciler oluşturmaktadır. Kayseri ili nufusu 2018 yılı verilerine göre 1.389 .680 kişi olarak kayıtlara geçmiştir. Kayseri ilindeki nufüs dikkate alındığında örneklem büyüklüğünün, araştırma evrenindeki bireylerinin sayısının bir milyon ve üzeri olması durumunda \pm 0,05 örnekleme hatası ile 384 (Sekeran, 1992) ya da 500.000, üzeri ana kütlelerde 322 (Kurtuluş, 1981) ve 380 (Yazıcı ve Erdoğan, 2004) olmasının yeterli olacağını ifade eden çalışmalar mevcuttur. Anket uygulamasına geçmeden önce 22 tüketiciye pilot uygulama yapılmak üzere taslak anket formları yönlendirilmiş ve anketlerde yanlış anlaşılmalara sebep olabilecek alanlara yönelik değerlendirme yapmaları talep edilmiştir. Araştırma Kayseri ilinde ikamet eden kullanıcılarla sınırlıdır. Yapılan değerlendirmeler sonrasında tesadüfi olmayan örnekleme yöntemlerinden kolayda örnekleme ile gerçekleştirilen yüz yüze anket metodu sayesinde araştırma kapsamında 387 veri Kasım 2018 - Ocak 2019 döneminde toplanmıştır. Bu doğultuda örnek büyüklüğünün yeterli olacağına karar verilmiştir. Hızlı ve az maliyetli olmasından dolayı Kolayda örnekleme yöntemi ile veriler elde edilmiştir (Nakip, 2006, s.204).

\section{Veri Toplama Aracı}

Anket formunda yer alan ölçekler, literatürde geçerlilik ve güvenirlikleri kanıtlanmış, ölçeklerden faydalanılarak çalışmaya uyarlanmıştır. Araştırmada kullanılan ölçekler marka bilinirliliği (Bravo vd., 2007; Im vd., 2012; Lehmann vd., 2008; Washburn ve Plank, 2002; Yoo ve Donthu, 2001; Shah, 2012; Tong ve Hawley, 2009), marka çağrışımları (Bravo vd., 2007; Washburn ve Plank, 2002; Yoo vd., 2000; Keller, 1993), algilanan 
kalite (Im vd. ,2012; Kim ve Hyun, 2011; Lehmann vd., 2008; Washburn ve Plank, 2002; Pappu vd., 2005; Shah, 2012; Tong ve Hawley, 2009), marka bağlılığı (Im vd., 2012; Pappu vd., 2005; Shah, 2012; Washburn ve Plank, 2002; Yoo ve Donthu, 2001; Yoo vd., 2000, Sung ve Kim, 2010; Yoo ve Donthu, 2001; Raju, Unnava ve Montgomery, 2009) ve marka imaj1 (Kim vd., 2003) çalışmalarından Türkçeye çevrilmiş ve araştırma konusuna uyarlanmıştır.

Araştırmanın amaçlarına uygun olarak hazırlanan anket formları kısa bir açıklama ardından üç ana bölümden oluşmaktadır. Birinci bölümünde, tüketicilerin bankacılık işlemlerinden faydalanıp faydalanmadıklarına yönelik bir soru sorulmuştur. Bu soru ile bankacılık işlemleri yapmayanların örneklem dışı bırakılması amaçlanmıştır. İkinci bölümünde ise, tüketicilerin marka denkliğinin boyutlarının ve marka imajının tespit edilmesi için marka çağrışımlarına yönelik 3 soru, marka bilinirliliğine yönelik 3 soru, algılanan kaliteye yönelik 10 soru, marka bağlılığına yönelik 7 soru ve marka imajına yönelik 7 sorudan olmak üzere toplam 30 ifade oluşturulmuştur. Anket formları yönelik 5'li likert tipi ölçek kullanılarak (1=kesinlikle katılmıyorum, 5=kesinlikle katılıyorum) hazırlanmıştır.

Üçüncü bölümde ise, katılımclların demografik özelliklerinin yer aldığı cinsiyet, yaş, medeni durum, öğrenim durumu gelir, en fazla hizmet alınan banka adı ifadeleri yer almaktadır. Anketlerin eksiksiz ve doğru bir şekilde cevaplanması için katılımcılara gerekli açıklamalar yapılmıştır. Anketler incelenmiş, analize uygun olmayan eksik, tutarsız ve hatalı olduğu tespit edilen veriler ayıklanmıştır. Veriler SPSS 22 paket programı ile analiz edilmiştir. Araştırmada uygulanan ölçeklerin güvenilirliği Cronbach's Alpha katsayısı kullanılarak hesaplanmıştır. Uygulanan ankette yer alan ölçeklerin güvenilirlikleri Tablo.1'de yer almaktadir.

Tablo 1. Ölçeklerin Güvenilirlik Sonuçları

\begin{tabular}{|c|c|c|c|}
\hline $\begin{array}{c}\text { Marka } \\
\text { Bilinirliği-Farkındalığı }\end{array}$ & $\begin{array}{c}\text { Marka } \\
\text { Çağrışımları }\end{array}$ & Algılanan Kalite & Marka Bağlılığı ${ }_{\text {İmajı }}^{\text {Marka }}$ \\
\hline 834 &, 826 &, 934 &, 854 \\
\hline
\end{tabular}


Ölçekteki değişkenlerin Cronbah's Alpha değerlerinin $0,80 \leq \alpha<1,00$ olması ölçeğin yüksek derecede güvenilir olduğunu göstermektedir (Kalayc1, 2009, s.322). Tablo 1'de yer alan güvenilirlik analizinden elde edilen sonuçlara göre araştırmada yer alan tüm ölçeklerin güvenilir olduğunu belirlenmiştir.

\section{Araştırmanın Amacı ve Hipotezleri}

Araştırma amacına yönelik oluşturulan ilişkileri tespit etmek için oluşturulan hipotezler aşağıda yer almaktadır.

- $\mathrm{H}_{1}=$ Demografik değişkenler (H1.a:cinsiyet, H1.b:öğrenim durumu, H1.c: medeni durum, H1.d:yaş, H1.e: gelir, H1.f: kullanım süresi) ile marka farkındalığı arasında istatistiksel olarak anlamlı bir ilişki vardir.

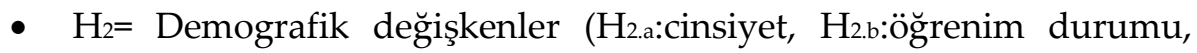
$\mathrm{H}_{2 . c \text { : }}$ medeni durum, $\mathrm{H}_{2}$.d:yaş, $\mathrm{H}_{2 . \text { e: }}$ gelir, $\mathrm{H}_{2}$.f: kullanım süresi) ile algılanan kalite arasında istatistiksel olarak anlamlı bir ilişki vardır.

- $\mathrm{H}_{3}=$ Demografik değişkenler $\mathrm{H}_{3 . a}$ :cinsiyet, $\mathrm{H}_{3 . b}$ :öğrenim durumu, H3.c:

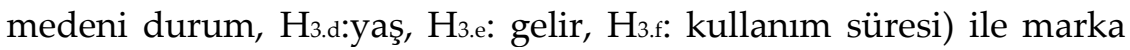
çağrışımları arasında istatistiksel olarak anlamlı bir ilişki vardır.

- $\mathrm{H}_{4}=$ Demografik değişkenler . (H4.a:cinsiyet, H4.b:öğrenim durumu, $\mathrm{H}_{4 . c}$ : medeni durum, $\mathrm{H}_{4 . d}$ :yaş, $\mathrm{H}_{4 . e}$ : gelir, $\mathrm{H}_{4 . \text { f: }}$ kullanım süresi) ile marka bağlılığı arasında istatistiksel olarak anlamlı bir ilişki vardır

- $\mathrm{H}_{5}=$ Marka farkındalığı ile marka imajı arasında istatistiksel olarak anlamlı bir ilişki vardır.

- $\mathrm{H}_{6}=$ Algılanan kalite ile marka imajı arasında istatistiksel olarak anlamlı bir ilişki vardır.

- $\quad H 7=$ Marka çağrışımları ile marka imajı arasında istatistiksel olarak anlamlı bir ilişki vardır.

- $\mathrm{H}_{8}=$ Marka bağlılığı ile marka imajı arasında istatistiksel olarak anlamlı bir ilişki vardır.

- $\mathrm{H}_{9}=$ Marka imajı ile marka denkliği arasında istatistiksel olarak anlamlı bir ilişki vardır.

Araştırmada yer alan değişkenlerin grupları arasında farklılı̆̆ın tespit edilmesi amacıyla oluşturulan hipotezler aşağıda yer almaktadır. 
- $\mathrm{H}_{1}=$ Demografik değişken grupları (H1.a:cinsiyet, H1.b:öğrenim durumu, $\mathrm{H}_{1 . c:}$ medeni durum, $\mathrm{H}_{1 . d}$ :yaş, $\mathrm{H}_{1 . e:}$ gelir, $\mathrm{H}_{1 . f:}$ kullanım süresi) ile marka farkındalığı arasında istatistiksel olarak anlamlı bir farklılık vardir.

- $\mathrm{H}_{2}=$ Demografik değişken grupları $\left(\mathrm{H}_{2}\right.$ a: cinsiyet, H2.b:öğrenim durumu, $\mathrm{H}_{2 . c \text { : }}$ medeni durum, $\mathrm{H}_{2 . d: y a s ̧, ~} \mathrm{H}_{2 . e:}$ gelir, $\mathrm{H}_{2 . f:}$ kullanım süresi) ile algılanan kalite arasında istatistiksel olarak anlamlı bir farklılık vardir.

- $\mathrm{H}_{3}=$ Demografik değişken grupları $\left(\mathrm{H}_{3}\right.$.a:cinsiyet, $\mathrm{H}_{3 . . b}$ öğrenim durumu, H3.c: medeni durum, $\mathrm{H}_{3 . d: y a s ̧, ~} \mathrm{H}_{3 . e:}$ gelir, $\mathrm{H}_{3 . f:}$ kullanım süresi) ile marka çağrışımları arasında istatistiksel olarak anlamlı bir farklılık vardir.

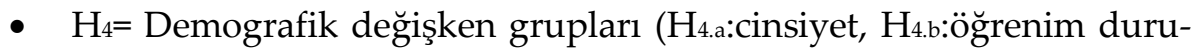

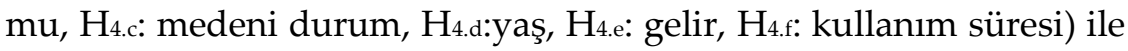
marka bağlılığı arasında istatistiksel olarak anlamlı bir farklılık vardir.

- $\mathrm{H}_{5}=$ Demografik değişken grupları (H5.a:cinsiyet, H5.b:öğrenim durumu, H5.c: medeni durum, H5.d:yaş, H5.e: gelir, H5.f: kullanım süresi) ile marka denkliği arasında istatistiksel olarak anlamlı bir farklılık vardır. $\mathrm{H}_{6}=$ Demografik değişken grupları ( $\mathrm{H}_{6 . a}$ :cinsiyet, $\mathrm{H}_{6 . b}$ :öğrenim durumu, H6.: medeni durum, H6.d:yaş, H6.e: gelir, H6.f: kullanım süresi) ile marka imajı arasında istatistiksel olarak anlamlı bir farklılık vardır.

\section{Bulgular}

Çalışmaya katılan tüketicilerin demografik özelliklere göre dağılımı çerçevesinde; cinsiyet, medeni durum, eğitim durumu, yaş, gelir düzeyleri ve banka kullanım durumuna ilişkin elde edilen bulgular değerlendirilmektedir. Araştırmada uygulanan anketler sonucunda demografik özelliklere ve kullanım süresine ilişkin frekanslar Tablo.2'de sunulmuştur.

Araştırmada yer alan katılımcıların \% 47.3'ünü kadınlar, \% 52.7'sını erkekler ve bu katılımcıların \%54.1'ini evliler, \%45.9'un bekarlar oluşturmaktadır. Katılımcılar \% 20.2'sinin ilköğretim, \% 33.2'sinin lise ve dengi, \%38.6'sının lisans, \%8'inin lisansüstü eğitim seviyesindedir. Katılımcıların \% 6.1'inin 20 yaş ve altı, \% 32.7'sinin 20-29 yaş arası 
olduğu, \% 33 'ünün 30-39 yaş, \% 21.4'ünün 40-49 yaş, \%6.9'unun 50 yaş ve üstü olduğu görülmektedir. Gelir seviyesi bakımından ise \%11.3'ünün gelirinin 500 ve alt1, \%39.1'inin gelirinin 501 ve 2000 arası, \%35.4' ünün 2001-3500 ve \% 14.2'sinin 3501 ve üzeri olduğu görülmektedir. Katılımciları banka kullanımında \%12.6'sının 1 yıl ve daha az süredir, \%39.8'inin 2-5 y1l, \%20.3'ünün 6-9 y1l, \%17.2'sinin 10-14 yıl, \%7.5'inin 15 yıl ve üzeri banka kullandıklarını belirtmişlerdir.

Tablo 2. Katılımcıların Demografik Özelliklere Göre Dağılımı

\begin{tabular}{|c|c|c|c|c|}
\hline Değişken & & $\mathbf{n}$ & $\%$ & Kümülatif \% \\
\hline \multirow{3}{*}{ Cinsiyet } & Kadın & 183 & 47,3 & 47,3 \\
\hline & Erkek & 204 & 52,7 & 100,0 \\
\hline & Total & 387 & 100,0 & \\
\hline \multirow{5}{*}{$\begin{array}{l}\text { Öğrenim } \\
\text { Durumu }\end{array}$} & İlköğretim & 78 & 20,2 & 20,2 \\
\hline & Lise ve Dengi & 128 & 33,2 & 53,4 \\
\hline & Lisans & 149 & 38,6 & 92,0 \\
\hline & Lisans Üstü & 31 & 8,0 & 100,0 \\
\hline & Total & 386 & 100,0 & \\
\hline \multirow{3}{*}{$\begin{array}{l}\text { Medeni } \\
\text { Durum }\end{array}$} & Evli & 209 & 54,1 & 54,1 \\
\hline & Bekar & 177 & 45,9 & 100,0 \\
\hline & Total & 386 & 100,0 & \\
\hline \multirow{6}{*}{ Yaş } & 20 ve altı & 23 & 6,1 & 6,1 \\
\hline & $20-29$ & 124 & 32,7 & 38,8 \\
\hline & $30-39$ & 125 & 33,0 & 71,8 \\
\hline & $40-49$ & 81 & 21,4 & 93,1 \\
\hline & 50 ve üzeri & 26 & 6,9 & 100,0 \\
\hline & Total & 379 & 100,0 & \\
\hline \multirow{5}{*}{ Gelir } & 500 ve alt1 & 43 & 11,3 & 11,3 \\
\hline & $501-2000$ & 148 & 39,1 & 50,4 \\
\hline & $2001-3500$ & 134 & 35,4 & 85,8 \\
\hline & 3501 ve üzeri & 54 & 14,2 & 100,0 \\
\hline & Total & 379 & 100,0 & \\
\hline \multirow{6}{*}{$\begin{array}{l}\text { Kullanım } \\
\text { Süresi }\end{array}$} & 1 yll ve daha az & 49 & 12,6 & 39,8 \\
\hline & $2-5$ yil & 155 & 39,8 & 79,7 \\
\hline & $6-9$ y1l & 79 & 20,3 & 100,0 \\
\hline & 10-14 y1l & 67 & 17,2 & 19,8 \\
\hline & 15 yıl ve üstü & 29 & 7,5 & 27,2 \\
\hline & Total & 379 & 100,0 & \\
\hline
\end{tabular}

Araştırma kapsamında belirlenen ölçekler, ifadeler ve tüketicilerin ölçek ifadelerine vermis olduğu katılım durumlarının ortalamaları ve standart 
sapmaları Tablo 3.'de sunulmuştur.

Tablo 3. Tüketicilerin Ölçek İfadelerine Katılımına İlişkin Göstergeler

\begin{tabular}{|c|c|c|c|c|}
\hline Ölçek & İfadeler & $\mathbf{n}$ & $\overline{\boldsymbol{X}}$ & ss \\
\hline \multirow{4}{*}{$\begin{array}{l}\text { Marka } \\
\text { Bilinirliliği }\end{array}$} & Bu bankanın farkındayım. & 377 & 3.42 & 1.008 \\
\hline & Bu bankayı çok iyi biliyorum. & 379 & 3.37 & .938 \\
\hline & Bu banka diğer bankalardan farklıdır. & 377 & 3.26 & .985 \\
\hline & ORTALAMA & & 3.35 & 0.98 \\
\hline \multirow{4}{*}{$\begin{array}{l}\text { Marka } \\
\text { Çağrışımları }\end{array}$} & Bu bankanın bazı özellikleri hızla aklıma geliyor. & 376 & 3.29 & .978 \\
\hline & Bu bankanın güçlü çağrışımları var. & 372 & 3.31 & .951 \\
\hline & $\begin{array}{l}\text { Bu bankanın sembolünü, reklamını, logosunu veya rengini hızlı bir } \\
\text { şekilde hatırlıyorum. }\end{array}$ & 375 & 3.56 & 1.008 \\
\hline & ORTALAMA & & 3.39 & 0.98 \\
\hline \multirow{11}{*}{$\begin{array}{l}\text { Algilanan } \\
\text { Kalite }\end{array}$} & Bu banka kalitelidir. & 377 & 3.42 & .931 \\
\hline & Bu banka katagorisindeki en iyi markadır. & 376 & 3.28 & .909 \\
\hline & $\begin{array}{l}\text { Katagorisindeki diğer markalara kıyasla, bu marka çok yüksek } \\
\text { kaliteye sahiptir. }\end{array}$ & 377 & 3.35 & .883 \\
\hline & $\begin{array}{l}\text { Bu banka katagorisindeki diğer bankaların hepsinden daha iyi } \\
\text { performans sergiliyor. }\end{array}$ & 377 & 3.33 & .903 \\
\hline & Banka modern araç-gereç ve teknolojiye sahiptir. & 377 & 3.44 & .958 \\
\hline & Bu banka sorunlarımı dikkate alıp, en uygun çözümü sağlar. & 378 & 3.44 & .923 \\
\hline & Bu banka iyi performans gösterir. & 378 & 3.46 & .871 \\
\hline & Bu banka vaatlerini yerine getirir. & 378 & 3.49 & .850 \\
\hline & Bu banka bana iyi hizmet etti. & 376 & 3.56 & .871 \\
\hline & Bu bankaya her zaman güvenebilirim. & 377 & 3.44 & .871 \\
\hline & ORTALAMA & & 3.42 & 0.90 \\
\hline \multirow{8}{*}{$\begin{array}{l}\text { Marka } \\
\text { Bağlılığı }\end{array}$} & Bu banka benim ilk tercihimdir. & 378 & 3.39 & .955 \\
\hline & $\begin{array}{l}\text { Rakip bankalar fiyat avantajı sağlasa bile mevcut bankamla çalışma- } \\
\text { ya devam ederim. }\end{array}$ & 378 & 3.34 & .983 \\
\hline & Bu bankadan tekrar hizmet satın almaya niyeyim var. & 377 & 3.41 & .944 \\
\hline & Farklı hizmete ihtiyaç duyduğumda yine bu bankayı kullanacağım. & 376 & 3.36 & .912 \\
\hline & Bu banka mevcut değilse diğer banka hizmetlerini kullanacağım. & 375 & 3.18 & 1.029 \\
\hline & $\begin{array}{l}\text { Başka bankayı seçmek zorunda kalırsam, benim için fazla fark } \\
\text { yaratmaz. }\end{array}$ & 375 & 3.35 & .903 \\
\hline & Çevremdeki insanlara kullandığım bankayı tavsiye ederim. & 376 & 3.40 & .927 \\
\hline & ORTALAMA & & 3.35 & 0.95 \\
\hline \multirow{8}{*}{ Marka İmajı } & Banka lükstür. & 375 & 3.31 & 1.003 \\
\hline & Banka pahalıdır. & 379 & 3.32 & 1.016 \\
\hline & Bu bankayı ziyaret ederek özel olmaya başladım. & 377 & 3.28 & 1.029 \\
\hline & Banka büyük ve ferahtır. & 377 & 3.41 & .913 \\
\hline & Banka sakin ve huzurludur. & 375 & 3.41 & .940 \\
\hline & Bankanın uzun bir geçmişi vardır. & 375 & 3.57 & .901 \\
\hline & Banka diğer banka markalarından farklı bir görüntü sergiliyor. & 376 & 3.51 & .836 \\
\hline & ORTALAMA & & 3.40 & 0.95 \\
\hline
\end{tabular}


Marka farkındalığının tüketiciler üzerinde yaratmış olduğu en büyük etki ise marka hakkında herhangi bir bilgiye veya çağrışıma sahip olmasalar bile satın alma kararlarında etkin rol oynamasıdır. Bunu gerçekleştirmenin yolu ise ilk önce tüketicilerin o ürünün veya markanın varlığının biliyor olmalarına bağlıdır (Sağlam, 2014, s.47). Müşterilerin banka tercihinde etkili olan faktörleri arasında marka farkındalığına yönelik sorular içerisinde 3,42 lük ortalama bankanın çok iyi bilindiği sonucuna ulaşılmıştır. Tüketiciler banka marka farkındalığı açısından incelendiğinde iyi bildikleri bankaları tercih ettikleri sonucuna ulaşılmaktadır. Tüketiciler 3,26'lık ortalama ile marka farkındalığında en düşük öneme sahip ifade olarak bankanın diğer bankalardan farklı olmasını ifade etmişlerdir.

Marka çağrışımlarına yönelik olan ifadeler içerisinde 3,56 ortalama ile bankanın sembol, reklam, logo ve rengini hızlı bir şekilde hatırlatması en yüksek değer olarak belirtilmiştir. Tüketiciler 3,29 ortalama ile en düşük öneme sahip olma açısından bankanın bazı özelliklerinin hızla akla gelmesi sonucuna ulaşılmıştır.

Algılanan kalite ilk olarak tüketiciye sunulan ürün ve hizmetin gerçek kalitesine bakılmaksızın kalite algısına yönelik değerlendirmede bulunup, satın alma aşamasında tüketicinin karar vermesine yardımcı olur. Bunula beraber bir işletmenin sahip olduğu ürünün veya markanın müşteriler tarafından belirlenmiş olan algılanan kalitesinin yüksek olması diğer ürün ve markalarının da algilanan kalitesinin yüksek olmasını kolaylaştıracaktır. Algılanan kalite açısından ifadeler incelendiğinde 3.56 ortalama ile bankanın sunduğu hizmet en önemli görülürken, ikinci sırada 3.49 ortalama ile bankanın vaatlerini yerine getirmesi olarak belirtilmiştir. Algılanan kalite ifadelerinden 3.28 ortalama ile bankanın katagorisindeki en iyi marka olması tüketiciler açısından daha az önemli bir faktör olduğu görülmektedir.

Tüketiciler marka bağlllı̆̆ı açısından incelendiğinde 3.41 ortalama ile "Bu bankadan tekrar hizmet satın almaya niyeyim var." ifadesi en yüksek puana sahipken, sonrasında 3.40 ortalama ile "Çevremdeki insanlara kullandığım bankayı tavsiye ederim." ifadesi belirtilmiştir. Tüketiciler "Bu banka mevcut değilse diğer banka hizmetlerini kullanacağım" ifadesine en alt seviyede katılarak bankalarına olan bağlılıklarını da ifade etmişlerdir. Marka imajı ölçek ifadelerinde 3.57 ortalama ile en 
yüksek puanı "Bankanın uzun bir geçmişinin olması" ifadesi sonrasında ise ikinci yüksek puanı 3.51 ortalama ile kullandıkları bankanın diğer banka markalarından farklı bir görüntü sergilemesi olarak belitrmişlerdir. Tüketiciler hizmet aldıkları bankayı ziyaret ederek özel olmaya başladıklarına yönelik ifadeye ise 3.28 puan vererek en alt seviyede değerlendirmişlerdir. Tüketicilerin bankaları, belirlenen ölçek ifadelerine göre değerlendirmelerinin sonucunda elde edilen puan ortalamaları, standart sapmaları ve varyaskon katsayıları Şekil.1'de verilmiştir. Varyasyon katsayısının verilmesinin sebebi puanlamadaki değişimin görülebilmesidir.

\begin{tabular}{|c|c|c|c|c|c|c|c|c|c|c|c|c|c|c|c|c|c|c|}
\hline ÖLC̣EK & \multicolumn{3}{|c|}{$\mathrm{MB}$} & \multicolumn{3}{|c|}{$\mathrm{MC}$} & \multicolumn{3}{|c|}{$A K$} & \multicolumn{3}{|c|}{$\mathrm{MBa}$} & \multicolumn{3}{|c|}{ MI } & \multicolumn{3}{|c|}{ ID } \\
\hline BANKA & $\overline{\bar{X}}$ & ss & VK & $\overline{\bar{X}}$ & ss & VK & $\overline{\bar{X}}$ & ss & IK & $\overline{\bar{X}}$ & ss & VK & $\bar{X}$ & ss & VK & $\overline{\bar{X}}$ & ss & VK \\
\hline DENIZZAANK & 3.78 & 0.73 & 0.19 & 3.83 & 0.90 & 0.24 & 3.51 & 0.70 & 0.20 & 3.41 & 0.60 & 0.18 & 3.06 & 0.65 & 0.21 & 3.63 & 0.65 & 0.18 \\
\hline YAPIKREDİ & 3.55 & 0.72 & 0.20 & 3.63 & 0.68 & 0.19 & 3.51 & 0.61 & 0.17 & 3.32 & 0.74 & 0.22 & 3.22 & 0.73 & 0.23 & 3.50 & 0.58 & 0.17 \\
\hline ING & 3.22 & 0.83 & 0.26 & 3.19 & 0.63 & 020 & 3.60 & 0.41 & 0.11 & 3.94 & 0.65 & 0.16 & 4.02 & 0.42 & 0.10 & 3.49 & 0.47 & 0.14 \\
\hline ZIRAAT BANK & 3.53 & 0.90 & 0.25 & 3.44 & 0.86 & 025 & 3.51 & 0.69 & 0.20 & 3.32 & 0.67 & 0.20 & 3.44 & 0.74 & 0.21 & 3.45 & 0.67 & 0.19 \\
\hline AKBANK & 3.39 & 0.83 & 0.24 & 3.43 & 0.87 & 025 & 3.51 & 0.69 & 0.20 & 3.42 & 0.92 & 0.27 & 3.63 & 0.75 & 0.21 & 3.44 & 0.70 & 0.20 \\
\hline FINANSBANK & 337 & 0.71 & 0.21 & 3.50 & 0.79 & 022 & 3.46 & 0.71 & 0.20 & 338 & 0.69 & 0.21 & 3.48 & 0.75 & 0.22 & 3.43 & 77 & 0.17 \\
\hline İ̧̧BANKASI & 3.33 & 1.10 & 0.33 & 3.42 & 0.93 & 027 & 3.49 & 0.93 & 0.27 & 3.45 & 0.81 & 0.24 & 3.45 & 0.93 & 0.27 & 3.42 & 0.83 & 0.24 \\
\hline HALKBANK & 3.12 & 0.69 & 0.22 & 3.25 & 0.75 & 0.23 & 339 & 0.62 & 0.18 & 3.44 & 0.58 & 0.17 & 3.49 & 0.68 & 0.19 & 3.30 & 0.55 & 0.17 \\
\hline GARANTI & 335 & 0.74 & 0.22 & 330 & 0.91 & 028 & 3.19 & 0.60 & 0.19 & 3.26 & 0.63 & 0.19 & 333 & 0.63 & 0.19 & 327 & 0.59 & 0.18 \\
\hline VAKIFBANK & 3.32 & 0.59 & 0.18 & 339 & 0.73 & 021 & 327 & 0.72 & 0.22 & 3.10 & 0.53 & 0.17 & 326 & 0.43 & 0.13 & 3.27 & 0.49 & 0.15 \\
\hline TEB & 3.24 & 0.78 & 0.24 & 3.26 & 1.08 & 0.33 & 3.31 & 0.63 & 0.19 & 3.24 & 0.80 & 0.25 & 337 & 0.96 & 029 & 3.26 & 0.73 & 0.22 \\
\hline FIBA BANK & 3.25 & 1.10 & 034 & 2.83 & 1.29 & 0.46 & 3.45 & 0.65 & 0.19 & 3.25 & 0.68 & 021 & 3.54 & 0.38 & 0.11 & 320 & 0.92 & 029 \\
\hline KUVEYTTÜRK & 2.79 & 0.47 & 0.17 & 3.08 & 0.64 & 0.21 & 330 & 0.49 & 0.15 & 330 & 0.55 & 0.17 & 2.98 & 0.32 & 0.11 & 3.12 & 0.30 & 0.10 \\
\hline URGANBANK & 3.00 & 1.19 & 0.40 & 3.25 & 0.88 & 0.27 & 3.03 & 0.70 & 0.23 & 3.07 & 0.41 & 0.13 & 3.43 & 0.40 & 0.12 & 3.09 & 0.74 & 0.24 \\
\hline
\end{tabular}

Şekil 1. Tüketicilerin Bankaları Ölçek Iffadelerine Göre Değerlendirmeleri

Marka denkliği ve alt ölçekleri bakımından bankalar değerlendirildiğinde marka bilinirliği açısından bakıldığında en yüksek puanı alan banka Denizbank (3.78) iken en düşük ortalamaya sahip banka Kuveyttürk (2.79), marka çağrışımları açısından en yüksek puanı alan banka Denizbank (3.83), en düşük ortalamaya sahip olan banka FibaBank (2.83), algılanan kalite açısından 3.60 ortalama ile ING Bankası en yüksek puanı alırken, en düşük puanı 3.03 ortalama ile UrganBank, marka bağlılığı açısından ise 3.94 puanla ING Bank birinci sırada yer alırken, en düşük puanı 3.07 ortalama ile Urgan Bank almıştır. Marka denkliğinde en yüksek ilk üç sırada Denizbank $(3,63)$, Yapıkredi Bankası 
(3.50) ve ING Bank (3.49) yer alırken, son üç sırada Urgan Bank, Kuveyttürk ve FibaBank yer almaktadır. Bankaların marka imajı değerlendirildiğinde ise 4.02 ortalama ile ING Bank, 3.63 ortalama ile akbank, 3.54 ortalama ile fiba bankası ilk üçe giren banka olduğu görülmektedir. En düşük ortalamalarda ise 2.98 ortalama ile Kuveyttürk, 3,06 ile DenizBank ve 3.22 ile Yapıkredi bankalarının yer aldığı tespit edilmiştir.

\section{Demografik özellikler, Marka İmajı, Marka Denkliği ve Alt Ölçekleri Arasındaki İlişki}

Araştırmada katılımcıların ölçeklere vermiş oldukları cevaplardan elde edilen sonuçların, Shapiro-Wilk normallik testine göre normal bir dağılım göstermemiş olmasından dolayı parametrik olmayan testler kullanılmıştır. Araştırmada Kullanılan Ölçekler ile demografik değişkenler arası Spearman Korelasyon Analizi Sonuçları Tablo 4'de sunulmuştur.

Marka bağlılığı ile;

- öğrenim durumu ile arasında istatistiksel olarak anlamlı negatif yönlü bir zayıf ilişki ( $\mathrm{p}=0.049$ ve $\mathrm{r}=-0.100)$,

- yaş arasında istatistiksel olarak anlamlı pozitif yönlü zayıf bir ilişki ( $\mathrm{p}=0.027$ ve $\mathrm{r}=0.114$ ),

- kullanım süresi arasında istatistiksel olarak anlamlı pozitif yönlü zayıf bir ilişki ( $\mathrm{p}=0.025$ ve $\mathrm{r}=0.115$ ) olduğu görülmüştür.

Kullanım süresi ile marka çağrışımları arasında istatistiksel olarak anlamlı pozitif yönlü zayıf bir ilişki vardır. ( $\mathrm{p}=0.00$ ve $\mathrm{r}=0.190)$ Yine kullanım süresi ile algılanan kalite arasında istatistiksel olarak anlamlı pozitif yönlü zayıf bir ilişki olduğu görülmüştür ( $\mathrm{p}=0.024$ ve $\mathrm{r}=0.115$ ). Marka denkliği ile bankanın kullanım süresi arasında ise istatistiksel olarak anlamlı pozitif yönlü zayıf bir ilişki olduğu tespit edilmiştir $(\mathrm{p}=0.004$ ve $\mathrm{r}=0.147)$.

Marka imajı ile ;

- Öğrenim durumu arasında istatistiksel olarak anlamlı negatif yönlü zayıf bir ilişki ( $\mathrm{p}=0.025$ ve $\mathrm{r}=-0.115)$,

- Marka çağrışımları arasında istatistiksel olarak anlamlı pozitif yönlü orta düzeyde bir ilişki ( $p<0,05$ ve $r=0,350)$, 
- Marka bilinirliği arasında istatistiksel olarak anlamlı pozitif yönlü orta düzeyde bir ilişki ( $\mathrm{p}<0,05$ ve $\mathrm{r}=0.571)$,

- Marka bağlılığı arasında istatistiksel olarak anlamlı pozitif yönlü zayıf bir ilişki ( $p<0,05$ ve $r=0.211)$,

- Algılanan kalite arasında istatistiksel olarak anlamlı pozitif yönlü orta düzey bir ilişki ( $p<0,05$ ve $r=0.387$ ),

- Marka denkliği arasında arasında istatistiksel olarak anlamlı pozitif yönlü orta düzey bir ilişki ( $p<0,05$ ve r=0.444) olduğu görülmüştür.

Tablo 4. Marka İmajı, Marka Denkliği ve Demografik Değişkenler Arasındaki Ilişkiler $(n=379)$

\begin{tabular}{|c|c|c|c|c|c|c|c|c|c|c|c|c|c|}
\hline 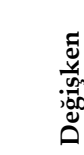 & & $\stackrel{\mu}{\Sigma}$ & $\underline{\Sigma}$ & 选 & $\sum_{\Sigma}^{\mathscr{E}}$ & $\Sigma$ & $\hat{\Sigma}$ & 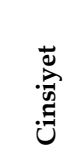 & 园 & 节泀 & 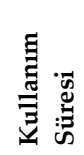 & 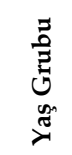 & 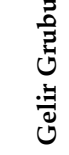 \\
\hline \multirow{2}{*}{ MB } & $\mathbf{r}$ & 1.000 & 711 & 687 & ,434 & ,350 & 871 & -.039 & .068 & .075 & .093 & .012 & .030 \\
\hline & p & & .000 & .000 & .000 & .000 & .000 & .450 & .186 & .145 & .072 & .818 & .560 \\
\hline \multirow{2}{*}{ MC } & $\mathbf{r}$ & 711 & 1.000 & 627 & ,349 & 211 & ,820 & -.018 & .096 & .057 & 190 & .040 & .066 \\
\hline & $\mathrm{p}$ & .000 & & .000 & .000 & .000 & .000 & .722 & .061 & .266 & .000 & .435 & .201 \\
\hline \multirow{2}{*}{ AK } & $\mathbf{r}$ & ,687 & 627 & 1.000 & ,564 & ,387 & ,860 & -.010 & .030 & .051 &, $116^{*}$ & .030 & .037 \\
\hline & p & .000 & .000 & & .000 & .000 & .000 & .841 & .566 & .327 & .024 & .567 & .471 \\
\hline \multirow{2}{*}{ МBa } & $\mathbf{r}$ & , 434 & ,349 & ,564 & 1.000 & ,571 & 680 & -.007 & -.100 & .025 & , $115^{*}$ & $114^{*}$ & .023 \\
\hline & $\mathbf{p}$ & .000 & .000 & .000 & & .000 & .000 & .893 & .049 & .630 & .025 & .027 & .652 \\
\hline \multirow{2}{*}{ MI } & $\mathbf{r}$ & ,350 & 211 & ,387 & ,571 & 1.000 & ,444 & -.021 &,$- 115^{*}$ & -.063 & .085 & .066 & -.009 \\
\hline & $\mathbf{p}$ & .000 & .000 & .000 & .000 & & .000 & .689 & .025 & .222 & .099 & .196 & .861 \\
\hline \multirow{2}{*}{ MD } & $\mathbf{r}$ & ,871 & 820 & 860 & ,680 & ,444 & 1.000 & -.026 & .037 & .067 & 147 & .046 & .066 \\
\hline & $\mathbf{p}$ & .000 & .000 & .000 & .000 & .000 & & .617 & .479 & .195 & .004 & .369 & .201 \\
\hline
\end{tabular}

Marka Imajı, Marka Denkliği ve Alt Ölçeklerin Demografik Özellik Gruplarının Düzeyine Göre Farklılaşma Durumu

Demografik değiş̧kenlere ve kullanım süresi değiş̧kenine göre bankaların algılanan kalite, marka bağlılığı, marka çağrışımları, marka bilinilirliği ve marka imajına yönelik istatistiki olarak farklılık gösterip göstermediğini test etmek için ise Mann whitney U testi ve Kruskal Wallis H- Testi uygulanmıştır. Bu bağlamda iki gruptan oluşan cinsiyet ve medeni durum değişkeni Mann Whitney $U$ testi ile incelenirken ve grup 
sayısının 2' den fazla olduğu diğer değişkenlerde Kruskal Wallis H testi uygulanmıştır. Ancak yapılan Mann Whitney U testi sonuçlarında istatistiksel olarak anlamlı bir farklılık elde edilememiştir. Anlamlı farklılığın tespit edildiği Kruskal Wallis H Testi sonuçları aşağıdaki gibidir. Varyansların homojenliği Levene test ile konrol edilmiş ve gruplarda homojenlik koşulunun sağlanmadığı görülmüştür. Bu sebeple gruplar arası farklarının kaynağını tespit edebilmek için Tamhane testi uygulanmıştır.

Tablo 5. Marka Denkliği Ölçeklerinin Demografik Değişken Grupları Arasındaki Farklilikları

\begin{tabular}{|c|c|c|c|c|c|c|c|c|}
\hline Değişken & & Grup & $\mathbf{N}$ & $\begin{array}{l}\text { Sira } \\
\text { Ort. }\end{array}$ & $\chi^{2}$ & sd & $\mathrm{p}$ & Tamhane \\
\hline \multirow{6}{*}{ Yaş } & \multirow{6}{*}{ MB } & 20 ve altı & 23 & 214.78 & \multirow{6}{*}{12.651} & \multirow{6}{*}{4} & \multirow{6}{*}{0.013} & \multirow{6}{*}{$\begin{array}{l}50 \text { ve üzeri }>20-29 \\
50 \text { ve üzeri }>30-39 \\
50 \text { ve üzeri }>40-49\end{array}$} \\
\hline & & $20-29$ & 124 & 187.07 & & & & \\
\hline & & $30-39$ & 125 & 186.05 & & & & \\
\hline & & $40-49$ & 81 & 173.06 & & & & \\
\hline & & 50 ve üzeri & 26 & 253.81 & & & & \\
\hline & & Total & 379 & & & & & \\
\hline \multirow{5}{*}{$\begin{array}{l}\text { Öğrenim } \\
\text { Durumu }\end{array}$} & \multirow{5}{*}{ MC } & İlköğretim & 77 & 190.62 & \multirow{5}{*}{8.284} & \multirow{5}{*}{3} & \multirow{5}{*}{0.041} & \multirow{5}{*}{$\begin{array}{l}\text { Lisansüstü > Lise } \\
\text { ve dengi }\end{array}$} \\
\hline & & Lise ve Dengi & 123 & 168.63 & & & & \\
\hline & & Lisans & 147 & 200.29 & & & & \\
\hline & & Lisans Üstü & 31 & 218.39 & & & & \\
\hline & & Total & 378 & & & & & \\
\hline \multirow{6}{*}{$\begin{array}{l}\text { Kullanım } \\
\text { Süresi }\end{array}$} & \multirow{6}{*}{ MC } & 1yıl ve daha az & 49 & 149.10 & \multirow{6}{*}{16.623} & \multirow{6}{*}{4} & \multirow{6}{*}{0.002} & \multirow{6}{*}{$\begin{array}{l}15 \text { yll ve üzeri } \\
>1 \text { yıl ve daha az }\end{array}$} \\
\hline & & $2-5 y_{11}$ & 155 & 182.40 & & & & \\
\hline & & $6-9 y 11$ & 79 & 202.33 & & & & \\
\hline & & 10-14yıl & 67 & 199.36 & & & & \\
\hline & & 15 ve üzeri & 29 & 244.53 & & & & \\
\hline & & Total & 379 & & & & & \\
\hline \multirow{6}{*}{$\begin{array}{l}\text { Kullanım } \\
\text { Süresi }\end{array}$} & \multirow{6}{*}{ AK } & 1yıl ve daha az & 49 & 143.49 & \multirow{6}{*}{13.911} & \multirow{6}{*}{4} & \multirow{6}{*}{.008} & \multirow{6}{*}{$\begin{array}{l}\text { 1yıl ve daha az< } \\
2-5 y 11 \\
1 \text { yıl ve daha az< } \\
15 y 1 \text { ve üzeri }\end{array}$} \\
\hline & & $2-5 y 11$ & 155 & 196.42 & & & & \\
\hline & & 6-9yıl & 79 & 195.46 & & & & \\
\hline & & 10-14y1 & 67 & 184.78 & & & & \\
\hline & & 15 ve üzeri & 29 & 231.43 & & & & \\
\hline & & Total & 379 & & & & & \\
\hline \multirow{6}{*}{$\begin{array}{l}\text { Kullanım } \\
\text { Süresi }\end{array}$} & \multirow{6}{*}{ MD } & 1yıl ve daha az & 49 & 151.83 & \multirow{6}{*}{15.064} & \multirow{6}{*}{4} & \multirow{6}{*}{.005} & \multirow{6}{*}{$\begin{array}{l}1 \text { yıl ve daha az< } \\
15 y \text { yl ve üzeri }\end{array}$} \\
\hline & & $2-5 y 11$ & 155 & 186.78 & & & & \\
\hline & & 6-9yıl & 79 & 203.86 & & & & \\
\hline & & 10-14y1l & 67 & 184.81 & & & & \\
\hline & & 15 ve üzeri & 29 & 245.95 & & & & \\
\hline & & Total & 379 & & & & & \\
\hline
\end{tabular}


Tablo 5'da görüldüğü üzere marka bilinirliği ile yaş grupları arasında 0.05 anlamlılık düzeyinde önemli bir farkın olduğu görülmektedir.Bu fark 50 yaş ve üstü olan katılımcılarla diğer tüm yaş grupları arasında görülmüştür. Öğrenim durumu ile marka çağrısımları arasında da lisansüstü öğrenim gören bireylerin lise ve dengi öğrenim gören bireylere göre marka çağrışımlarının yüksek olduğu görülmektedir. Marka çağrışımları, algılanan kalite ve marka denkliği ölçeklerine göre bankaların kullanım süresi grupları arasındaki farklar istatistiksel olarak anlamlıdır. Yani bankaların kullanım süresi grubuna göre 15 yıl ve üzeri olanların, 1yıl ve daha az olanlardan marka çağırışımı, algılanan kalite ve marka denkliklerinin daha yüksek olduğu anlaşılmıştır.

\section{Sonuç}

Rekabetin sürekli giderek arttığı günümüzde işletmelerin sunduğu ürün ve hizmetleri diğerlerinden ayırabilecek bir özellik kazandırabilmek için tüketicilerin gözünde olumlu tutum ve davranış oluşturabilecek çalışmaların yapılması zorunlu hale gelmiştir. İşletmeler tarafından marka imajı ve marka denkliğinde yer alan algılanan kalite, marka bağlılığı, marka çağrışımları ve marka bilinirliliği alt boyutlarda elde edilen olumlu sonuçların tüketicilerin marka tercihlerde rekabet üstünlüğü sağlamaktadır (Keller, 1993, s.1; Aaker, 1991, s.46).

$\mathrm{Bu}$ araştırmada, Kayseri ilinde yaşayan tüketicilerin tercih ettikleri bankalara göre demografik özelliklerinin, marka denkliği ve marka imajı üzerindeki etkilerinin ölçülerek ve demografik değişken grupları arasında bazı farklılıkların ortaya çıkarılabilmesini sağlamıştır. Kuramsal çerçevede Aaker (1991) ve Keller (1993) tarafından geliştirilen marka denkliği modelleri temel alınarak ölçek ifadeleri literatür araştırması sonucunda oluşturulmuştur. Araştırma zaman ve ekonomik kısıtlar çerçevesinde gerçekleştirilmiştir. Yapılan anket uygulamaları sonucunda 387 anket elde edilmiştir. Tüketicilerin uzun bir geçmişi olan, iyi bildikleri, sembol, reklam, logo ve rengini hızlı bir şekilde hatırladıkları, iyi hizmet aldıkları ve vaadleri yerine getiren bankaları tercih ettikleri görümektedir. Bunun sonucu olarak hizmet alınan bankadan tekrar hizmet almaya niyetli olunduğu belirtilerek marka saadakatini vurgulanmaktadır. Bankaların diğer bankalardan farklılaşması, katego- 
risindeki en iyi banka olması, bazı özelliklerinin hızla akla gelmesi tüketicilerin banka tercih puanlamasında daha az öneme sahip olduğu görülmektedir.

Marka denkliğinde en yüksek ilk üç sırada Denizbank Yapıkredi Bankası ve ING Bank, son üç sırada Urgan Bank, Kuveyttürk ve FibaBank yer almaktadır. Bankaların marka imajı değerlendirildiğinde ING Bank, Akbank ve Fiba bankası en yüksek üç puanı almaktadır.

Marka bağl1lı̆̆ ile öğrenim durumu, yaş ve banka kullanım süresi arasında zayıf bir ilişki olduğu, kullanım süresi ile marka çağrışımı, algılanan kalite ve marka denkliği arasında zayıf bir ilişki olduğu tespit edilmiştir. Marka imajı ile marka çağrışımları, marka bilinirliği, algılanan kalite, marka denkliği arasında orta düzey bir ilişki olduğu görülmüştür. Yaş grupları açısından incelendiğinde 50 yaş ve üstü olan katılımclarıda marka bilinirliğinin daha yüksek, lisansüstü öğrenim gören bireylerin lise ve dengi öğrenim gören bireylere göre marka çağrışımlarının daha yüksek, bankalarda kullanım süresi 15 yıl ve üzeri olan katılımcılarda, 1yıl ve daha az olanlara göre marka çağırışımı, algılanan kalite ve marka denkliklerinin daha yüksek olduğu anlaşılmıştır.

$\mathrm{Bu}$ sonuçlardan yola çkarak işletmelerin, marka denkliği oluşumunda etkili olan algılanan kalite, marka bağlılığı, marka farkındalığ1 ve marka çağrışımları gibi boyutlara daha fazla önem vermeleri gerektiği söylenebilir. Ayrıca işletmelerin, müşteri potansiyelini artırabilmeleri için marka denkliği boyutlarının yanı sıra, marka imajı faktörünü de göz önüne alarak imajlarını artırmaları gerekmektedir. Araştırmada elde edilen bulguların farklı çalışmalarla da desteklediği görülmüştür (Ural ve Perk, 2012; Aaker, 1991; Sirgy ve Su, 2000; Dodds ve diğ., 1991) İşletmelerin dikkat etmeleri gereken bir diğer konu ise, tüketicilerin satın alma davranışlarında etkili olan demografik faktörlerdir. Araştırma analiz sonuçlarının da kısmen desteklediği gibi demografik faktörlerin bazılarının marka imajı, marka bağlılığı, marka farkındalığı, algılanan kalite ve marka çağrışımları üzerinde de etkileri söz konusu olmaktadır. Sonuç olark marka denkliği boyutlarını ve marka imajını iyileştirecek ve geliştirecek çözümler oluşturmak bankalar için önemli bir marka stratejisi olarak görülmelidir.

Gelecek araştırmaları farklı coğrafi bölgelerde farklı ürün, ürün grubu ve hizmetler üzerinde test edilmesi marka denkliğinin daha iyi anlaşıl- 
masına imkan sağlayacaktır. Konum bazlı system entegrasyonu sağlanarak araştırmanın mekansal açıdan da değerlendirmesi sağlanabilir. Ayrıca günümüzde bankaların online platformları, sosyal ağları ve uygulamaları aktif olarak kullandıkları göz önüne alındığında, araştırmanın bu kapsamda digital boyutları da dahil ederek geliştirilmesi araştırmacılara farklı bir bakış açısı kazandıracaktır. Sonuç olarak tüketici gözünde markaya denkliği yüksek bir markaya sahip olmak ve etkili bir şekilde yönetmek için işletmelerin çalışmada incelenen boyutlar ve ilave olarak incelenebilecek farklı boyutlarında etkileri araştırmalı, analiz edilmeli ve stratejik bir yönetim anlaysşla bu süreci değerlendirerek yönetmelidirler. 


\title{
EXTENDED ABSTRACT
}

\section{Evaluating The Relationship Between Brand Equity and Image of Customers Bank Preferences}

\author{
Burcu Oralhan - Nuh Mehmet Özlü \\ Nuh Naci Yazgan University
}

Today, a strong brand is one of the most important assets of any business aiming at sustainable growth under international integration and challenging competition. Along with technological developments, changes in the banking sector related to products and services have accelerated the competitive environment. The importance of brand image, brand equity and brand equity in terms of perceived quality, brand connotations, brand awareness and brand loyalty has started to be understood in the evaluation of brands for products and services offered by enterprises. The aim of this study is to determine the relationships between the demographic characteristics of the consumers who benefit from banking services and the brand equity of the banks they prefer, the subdimensions of the equity and the brand image and also to determine the differences between the demographic variables. For this purpose, 387 questionnaires were applied to consumers residing in Kayseri on November 2018- January 2019 and scale reliability was calculated. Brand equity model developed by Aaker and Keller, which consist of brand awareness, brand loyalty, perceived quality and brand associations, is discussed in this research. Data were obtained by easy sampling method since it is fast and less expensive. In the first part of the questionnaires prepared in accordance with the aims of the research, there is a question about whether consumers benefit from banking transactions and in the second part, there are statements about measuring the dimensions of the brand equity of consumers. The questionnaires were prepared using a 5 point Likert scale.

In the scope of the research, data analysis was done by using SPSS 22 package program with the help of descriptive statistics, Spearman correlation and Kruskal Wallis analysis. The Cronbach's Alpha values of the scales were $0.80 \leq \alpha<1.00$, indicating that the scales were highly reliable. 
$47.3 \%$ of the participants were women, $52.7 \%$ were men and $54.1 \%$ of them were married and $45.9 \%$ were single. $20.2 \%$ of the participants are in primary education, $33.2 \%$ are in high school and equivalent level, $38.6 \%$ are in undergraduate and $8 \%$ are in graduate level. It is seen that $6.1 \%$ of the participants are 20 years and under, $32.7 \%$ are between $20-29$ years, $33 \%$ are $30-39$ years, $21.4 \%$ are $40-49$ years, $6.9 \%$ are 50 years and over. In terms of income level, it is seen that $11.3 \%$ of income is between 500 and below, $39.1 \%$ of income is between 501 and 2000, 35.4\% of 20013500 and $14.2 \%$ of it is 3501 and above. $12.6 \%$ of the participants used the bank for 1 year or less, $39.8 \%$ for $2-5$ years, $20.3 \%$ for $6-9$ years, $17.2 \%$ for $10-14$ years, $7.5 \%$ for 15 years or more they have used.

In the statements regarding brand awareness, the bank is well known; quick reminding of the bank's symbol, advertisement, logo and color in expressions aimed at brand associations; the service provided by the bank when the statements in terms of perceived quality are examined; In terms of brand loyalty, "I have the intention to buy services from the bank again" statements have the highest scores. When evaluating banks in terms of brand equity and sub-scales, Denizbank (3.78) was the bank with the highest score in terms of brand awareness, while Kuveyttürk (2.79) was the bank with the lowest average, Denizbank (3.83) was the lowest in terms of brand associations. The bank FibaBank (2.83) received the highest score of ING Bank with an average of 3.60 in terms of perceived quality, UrganBank with the lowest score of 3.03, and ING Bank with the highest score of 3.94 in terms of brand loyalty, and Urgan Bank with the lowest score of 3.07. The top three brands are Denizbank (3.63), Yapikredi Bank (3.50) and ING Bank (3.49), while Urgan Bank, Kuveyttürk and FibaBank are the last three. When the brand image of the banks is evaluated, it is seen that ING Bank with 4.02 average, Akbank with 3.63 average and Fiba with 3.54 average are the top three banks.

According to the results of the analyzes, the relationships between brand loyalty and educational status, age and bank usage period and the relationships between the usage period and perceived quality, brand equiva-lence and brand connotations were determined. There were also relations between brand image and brand associations, brand awareness, perceived quality and brand equity. When the age groups are examined, it is seen that the brand awareness is higher in the participants aged 50 
and over and indi-viduals with postgraduate education have higher brand associations than high school and equivalent students. Furthermore, it is understood that the number of brand call, perceived quality and brand balances were higher than those with 1 year or less in the banks with a usage period of 15 years or more. As a result, enterprises need to increase their customer potential by evaluating the customers according to their demographic characteristics and increasing their image by considering the dimensions of brand equity together. Establishing solutions to improve and develop brand equity dimensions and brand image should be identified as an important brand strategy for banks.

\section{Kaynakça / References}

Aaker, D. A. (1991). Managing brand equity: Capitalizing on the value of a brand name. New York: The Free Press.

Aaker, D. A. (1996). Measuring brand equity across products and markets. California management review, 38(3), 102-120.

Alemdar, M. Y. ve Dirik, Ç. (2016). Tüketici temelli marka denkliği: Gazete markaları örneği. Ordu Üniversitesi Sosyal Bilimler Araştırmaları Dergisi, 6(3), 811-838.

Bravo, G. R., Fraj, A. E. ve Martinez, S. E. (2007). Family as a source of consumer-based brand equity. Journal of product and brand management, 16(3), 188-199.

Çetin, S., ve Tekiner, M. A. (2015). Kurumsal imajin temel beliriyicileri: emniyet teşkilati örneklemi iç paydaş anketi. Yönetim ve Ekonomi Araştırmaları Dergisi, 13(1), 418-440.

Dodds, W. B., Monroe, K. B., ve Grewal, D. (1991). Effects of price, brand, and store information on buyers' product evaluations. Journal of marketing research, 28(3), 307-319.

Eyüpgiller, S. (1988). Bankacilar için banka işletmeciliği bilgisi. Ankara: Banka ve Ticaret Hukuku Araştırma Enstitüsü Yayını.

Hoeffler, S. ve Keller, K.L. (2003). The Marketing advantages ofstrong brands, Brand Management, 10(6), 421- 445.

Im, H. H., Kim, S. S., Elliot, S., ve Han, H. (2012). Conceptualizing destination brand equity dimensions from a consumer-based brand equity perspective. Journal of Travel and Tourism Marketing, 29(4), 385-403. 
İslamoğlu, A. H., ve Fırat, D. (2011). Stratejik marka yönetimi. İstanbul: Beta Yayınevi.

Kalaycı, Ş. (2009). SPSS uygulamalı çok değişkenli istatistik teknikleri. (Ş. Kalaycı Ed.), Ankara: Asil Yayınevi.

Karacan, D. (2006). Müşsteri-odakli marka denkliği ve marka denkliği unsurlarina yönelik tüketici tutumlarinin ölçülmesi: otel işletmeleri üzerine bir uygulama. Yüksek Lisans Tezi, Çukurova Üniversitesi Sosyal Bilimler Enstitüsü, Adana.

Keller, K. L. (1993). Conceptualizing,measuring and managing customerbased brand equity. Journal of Marketing, 57(1),1-22.

Kim, H. B., Gon Kim, W., ve An, J. A. (2003). The effect of consumer-based brand equity on firms' financial performance. Journal of Consumer Marketing, 20(4), 335-351.

Koçoğlu, C. M., ve Aksoy, R. (2017). Tüketici temelli marka denkliği bileşenleri arasindaki ilişkiler üzerine bir araştirma. International Journal of Economic and Administrative Studies, 18, 71-90.

Kurtuluş, K. (1981). Pazarlama araştırmaları. Genişletilmiş 2.Bsm, İstanbul: Üniversitesi İşletme Fakültesi.

Kuşakçıŏlu, A. (2003). Marka kimliği, kurum kimliği ve aralarındaki bağıntı. Yüksek Lisans Tezi, Ankara Universitesi Sosyal Bilimler Enstitüsü, Ankara.

Lassar, W., Mittal, B., ve Sharma, A. (1995). Measuring customer-based brand equity. Journal of consumer marketing, 12(4), 11-19.

Lehmann, D. R., Keller, K. L., ve Farley, J. U. (2008). The structure of surveybased brand metrics. Journal of International Marketing, 16(4), 29-56.

Nakip, M. (2006). Pazarlama araştırmaları, teknikler ve (SPSS destekli) uygulamalar. Ankara: Seçkin Yayıncılık.

Pappu, R., Quester P.G. ve Cooksey, R.W. (2006), Consumer-based brand equity and country-of-origin relationships, European Journal of Marketing, 40(5/6), 697-717.

Raju, S., Unnava, H. R., ve Montgomery, N. V. (2009). The moderating effect of brand commitment on the evaluation of competitive brands. Journal of Advertising, 38(2), 21-36.

Sağlam, M. (2014). Müşteri temelli marka denkliği unsurlarinin tüketici satin alma niyeti üzerine etkisi: Gsm sektöründe bir uygulama. Yüksek Lisans Tezi, İstanbul Ticaret Üniversitesi, Sosyal Bilimler Enstitüsü, İstanbul. 
Shah, R. B. (2012). A confirmatory factor analysis on brand equity in mobile handset market: SEM approach. IUP Journal of Brand Management, 9(3), 40.

Sekaran, U. (1992). Research methods for business: A skill building approach. New York: WileyveSons Inc.

Severi, E., ve Ling, K. C. (2013). The mediating effects of brand association, brand loyalty, brand image and perceived quality on brand equity. Asian Social Science, 9(3), 125-137.

Sirgy, M. J., ve Su, C. (2000). Destination image, self-congruity, and travel behavior: Toward an integrative model. Journal of Travel Research, 38(4), 340-352.

Silsüpür, Ö. (2014). Üniversite öğrencilerinin gözünde İstanbul Üniversitesi'nin imajı. Yüksek Lisans Tezi, Selçuk Üniversitesi Sosyal Bilimler Enstitüsü, Konya.

Subramaniam, A., Al Mamun, A., Permarupan, P. Y., ve Zainol, N. R. B. (2014). Effects of brand loyalty, image and quality on brand equity: A study among bank Islam consumers in Kelantan, Malaysia. Asian Social Science, 10(14), 67.

Sung, Y., ve Kim, J. (2010). Effects of brand personality on brand trust and brand affect. Psychology ve Marketing, 27(7), 639-661.

Sümer, G. (2016). Türk bankacılık sektörünün tarihsel gelişimi ve $A B$ bankacılık sektörü ile karşilaştirilması. Gazi Üniversitesi İktisadi ve İdari Bilimler Fakültesi Dergisi, 18(2), 485-508.

Tepegöz, Ş. M. (2012). Bankacıllk sektöründe çalişan ile müşteri arasındaki iletişimin müşteri memnuniyetine etkisi ve önemi. Yüksek Lisans Tezi, Karadeniz Teknik Üniversitesi, Sosyal Bilimler Enstitüsü, Trabzon.

Tong, X., ve Hawley, J. M. (2009). Measuring customer-based brand equity: empirical evidence from the sportswear market in China. Journal of Product and Brand Management, 18(4), 262-271.

Ural, T., ve Perk, H. G. (2012). Tüketici temelli marka değerinin kişisel bilgisayar satın alma niyeti üzerine etkisi: Antakya'da bir çalışma. Anadolu Üniversitesi Sosyal Bilimler Dergisi, 12 (3), 11-25.

Vuran, Y., ve Afşar, A. (2016). İşletmelerde marka ve marka stratejileri. International Journal of Academic Value Studies, 2(6), 28-39.

Washburn, J. H., ve Plank, R. E. (2002). Measuring brand equity: An evaluation of a consumer-based brand equity scale. Journal of Marketing Theory and Practice, 10(1), 46-62. 
Yaprakli, Ş. ve Can P. (2009). Pazarlama faaliyetlerinin ve ailenin tüketici temelli marka değeri boyutlarına etkisi, Atatürk Üniversitesi İ̈BF Dergisi, 23(1), 265-290.

Yazıcıoğlu, Y. ve Erdoğan, S. (2004). SPSS uygulamalı bilimsel araştırma yöntemleri. Ankara: Detay Yayıncilık.

Yoo, B., ve Donthu, N. (2001). Developing and validating a multidimensional consumer-based brand equity scale. Journal of business research, 52(1), 1-14.

Yoo, B., Donthu, N., ve Lee, S. (2000). An examination of selected marketing mix elements and erand equity. Journal of The Academy of Marketing Science, 28(2), 195-211.

\section{Kaynakça Bilgisi / Citation Information}

Oralhan, B. ve Özlü, M.N. (2019). Tüketicilerin banka tercihlerinde marka denkliği marka imajı arasındaki ilişkinin değerlendirilmesi. OPUS-Uluslararası Toplum Araştırmaları Dergisi, 13(19), 1255-1282. DOI: 10.26466/opus.563431 